Doktoral Ilmu Hukum, Fakultas Hukum, Universitas Lampung, Bandar Lampung, Lampung, Indonesia.

Volume 2 Issue 2, January-June 2021: pp: 133-140 http://jurnal.fh.unila.ac.id/index.php/plr P-ISSN: 2723-262X E-ISSN: 2745-9306

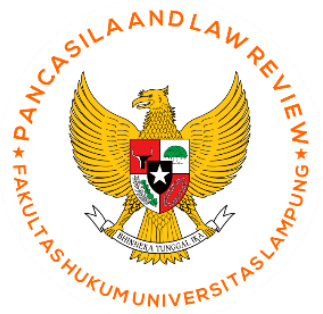

\title{
Pancasila as The Basis of The State Unity of The Republic of Indonesia
}

\author{
Palmawati Taher \\ Universitas Sultan Agung Tirtayasa, Indonesia \\ palmawatitaher@untirta.ac.id
}

Submitted: Oct 11, 2021; Reviewed: Nov, 29, 2021; Accepted: Dec 1, 2021

\begin{tabular}{|c|c|}
\hline Article's Information & Abstract \\
\hline Keywords : Pancasila; Unity & Abstract \\
\hline $\begin{array}{l}\text { DOI } \\
\text { https://doi.org/10.25041/plr.v2i2 } \\
.2449\end{array}$ & $\begin{array}{l}\text { Indonesia is facing various challenges because some } \\
\text { people do not use religious and cultural values as a } \\
\text { source of ethics in the nation and state. Socio-cultural } \\
\text { conflicts have occurred due to ethnic, cultural, and } \\
\text { religious pluralism that the government and society are } \\
\text { not appropriately managed and fair. Based on that, } \\
\text { Pancasila is needed by all generations of the nation. The } \\
\text { type of research method used in this research is } \\
\text { normative research, namely research on library } \\
\text { materials which are primary data in science is classified } \\
\text { as secondary data, which relies on data collection tools } \\
\text { in the form of library studies or document studies. The } \\
\text { research concludes that generations need Pancasila to } \\
\text { unify the nation. Even though the Indonesian people are } \\
\text { now united, it does not mean that Pancasila is no longer } \\
\text { needed. Because what is called the Indonesian nation is } \\
\text { what is currently there and what will exist in the future. } \\
\text { As long as the regeneration process continues, we still } \\
\text { need Pancasila as a unifying nation. }\end{array}$ \\
\hline
\end{tabular}

A. Introduction

A nation needs to have a state basis because the state basis is a sign for the direction of a government to be following the aspired goals. In line with the Preamble to the 1945 Constitution of the Republic of Indonesia (the 1945 Constitution of the Republic of Indonesia), the ideals of Indonesian independence are to create a just and prosperous society based on Pancasila. ${ }^{1}$

Thus, then, Pancasila is not only the basis of the state, but at the same time, it has also become the goal of the life of the nation and state. With the Pancasila state basis and the goal

${ }^{1}$ Muhammad Yamin, Naskah Persiapan Undang-Undang Dasar 1945 (Jakarta: Jajasan Prapantja, 1959). 
of a just and prosperous society based on Pancasila, inevitably, the guidelines or ways to achieve that goal must also be Pancasila. It can be said, from (the basis of) Pancasila with (guidelines) Pancasila for Pancasila. If one of these components is not met, then realising a prosperous society based on Pancasila may not be realised. ${ }^{2}$

Like democracy, it is from the people-by the people-for the people. If one of these components is replaced or not fulfilled, then it means that it is no longer democratic. For example, from the people-not by the people-for the people, then it is not a democracy anymore. Another example, from the people-by the people-but not for the people, nor is it democracy. Moreover, if it is not from the people-by the people-for the people, it is also not democracy. Therefore, democracy in Indonesia must be guided by Pancasila to implement a Pancasila society. If this is not fulfilled, then the Pancasila state basis, Pancasila guidelines, and goals are also impossible to materialise. ${ }^{3}$

This kind of reality shows that the meaning and function of Pancasila is not only the basis of the state but also has more and more meanings and functions. The position and function of Pancasila can be:

1. Pancasila is the soul of the Indonesian nation

This means Pancasila is closely attached to the life of the Indonesian nation and determines the existence of the Indonesian nation. All activities of the Indonesian people are encouraged by Pancasila.

2. Pancasila is the personality of the Indonesian nation

This means that the Indonesian people's mental attitude, behaviour, and deeds have characteristics that can distinguish them from other nations. These characteristics are considered a nation's personality, and the Indonesian personality is Pancasila.

3. Pancasila is the way of life of the Indonesian people

This means that the values contained in Pancasila are used as a guide, guide, and guide in regulating the attitudes and behaviour of Indonesian people in the life of society, nation and state.

4. Pancasila is the philosophy of life of the Indonesian people.

Philosophy comes from the Greek word Philosophia. Philos or philein means to love (to love or look for). Sophia means wisdom, wisdom or truth. So literally, philosophy means loving the truth. Thus, Pancasila as the philosophy of life of the Indonesian people means that Pancasila by the Indonesian people is believed to have the truth. Philosophy also means a view of life, an attitude to life, a way of life, or a guide to life.

5. Pancasila as the weltanshauung of the Indonesian nation or as the philosophische grondslag of the Indonesian nation

These words were spoken by Ir. Soekarno in his speech on June 1, 1945, before the The Investigating Committee for Preparatory Work for Independence (BPUPKI) meeting. Welt means world, weltanshauung means view. In the German-English dictionary, weltanschauung means conception of the world, philosophy of life. Thus, weltanschauung means worldview, philosophy of life, or philoshopischegrondslag (philosophy foundation).

6. Pancasila is the noble agreement of the Indonesian people

This means that Pancasila has been agreed upon and approved by the Indonesian people through debate and exchange of ideas both in the BPUPKI and The Preparatory Committee for Indonesian Independence (PPKI) sessions by the country's founders. The state and nation of Indonesia maintain this noble agreement. We all have a promise to implement, maintain and submit to the principles of Pancasila.

\footnotetext{
${ }^{2}$ G Moedjanto, Pancasila: Buku Panduan Mahasiswa (Jakarta: Gramedia Pustaka Utama, 1989).

${ }^{3}$ Padmo Wahyono, Bahan-Bahan Pedoman Penghayatan Dan Pengamalan Pancasila (Jakarta: Rineka Cipta, 1993).
} 
7. Pancasila is the Foundation of Indonesia

This means that Pancasila is used as the basis and guidance in regulating government and state administration. The content and purpose of all legislation in Indonesia must be based on Pancasila and must not conflict with the spirit of Pancasila. Pancasila, in this sense, is referred to in the Preamble to the 1945 Constitution. ${ }^{4}$

8. Pancasila is the ideal foundation.

This sentence is contained in the decision of the People's Consultative Assembly regarding the Outlines of State Policy. The ideal basis for the Outline of the State Policy (GBHN) is Pancasila.

The meaning and function of Pancasila are many more, one of which is Pancasila as a unifying nation. Pancasila as a unifying nation is contained in the third principle of Pancasila, namely the Precepts of Indonesian Unity. This means that Pancasila strongly emphasises and upholds national unity. ${ }^{5}$ This means that Pancasila is also a unifying tool for the nation. The mention of the precepts of the Indonesian unity at the same time also shows that the Indonesian people have differences. Is there differences in language (region), ethnicity, culture, interest groups, politics, even religion? This means that the nation's leaders, especially those involved in the formulation of the actual state, understand and at the same time have great respect for the differences that exist in Indonesian society. They also realise that differences can cause division of the nation, and therefore they are also very aware of the importance of unity for the Indonesian nation. The inclusion in realising a nation's survival through unit shows that differences are a reality that humans cannot eliminate.

The difference is wise to be grateful for and not something to be denied. Moreover, it must be removed from the face of this earth. The difference is also a nature that exists everywhere, in any country and nation. In response to this kind of reality, the solution is unavoidable is to make the existing differences a wealth that must be upheld by prioritising the unity and integrity of the nation above personal, group and regional interests. In the national discourse, the barometer that must be upheld is the national interest, not smaller, lower, or narrower interests. With this kind of awareness, it is clear that national unity is a noble value that all human beings should uphold. Because, in essence, division or conflict will destroy humanity itself. ${ }^{6}$

The verse of Bhineka Tunggal Ika is very appropriate to reflect on its essence and truth. Because essentially all nations, all humans need unity and cooperation among human beings. Cooperation requires unity, and unity requires peace. Therefore, division of the unity's opposition needs to be avoided and removed from the life of society, nation, and state. From this explanation, we are increasingly aware and aware that the Precepts of Unity of Indonesia are very appropriate to be included in the basis of the state, considering the truth and needs faced by all humanity.

\section{B. Discussion}

At present, the Indonesian people are facing various challenges; even though it has been a decade of reform, these challenges, if identified per People's Consultative Assembly (MPR) ${ }^{7}$ Decree Number V/MPR/2000 concerning Consolidating National Unity and the current condition of the Indonesian nation, are as follows:

1. Some people do not use religious and national cultural values as a nation's source. This then gave birth to a moral and moral crisis in the form of injustice, law violations, and human rights violations.

\footnotetext{
${ }^{4}$ Notonagoro, Pancasila Dasar Falsafah Negara (Jakarta: Bina Aksara, 1988).

${ }^{5}$ Sunoto, Mengenal Filsafat Pancasila (Etika Pancasila), 3rd ed. (Yogyakarta: UII Press, 1982).

6 Pranoto Iskandar, "The Pancasila Delusion," Journal of Contemporary Asia 46, no. 4 (2016): 723-35, https://doi.org/10.1080/00472336.2016.1195430.

${ }^{7}$ Majelis Permusyawaratan Rakyat or People's Consultative Assembly
} 
2. Socio-cultural conflicts have occurred because of ethnic, cultural, and religious pluralism that the government and society are not adequately and fairly. ${ }^{8}$

3. Law enforcement is not going well, and its implementation has been distorted so that it is contrary to the principle of justice, namely, equal rights of citizens before the law.

4. The ongoing economic behaviour with the practice of corruption, collusion, and nepotism and the lack of partiality to small and medium-sized business groups has caused a prolonged economic crisis. These large debts must be borne by the state, increasing unemployment and poverty and socio-economic disparities, which is getting wider.

5. The political system is not working well, so it has not been able to produce trustworthy leaders, set an example, and fight for the interests of the community.

6. The transfer of power that often causes conflict, bloodshed, and resentment between community groups occurs due to the democratic process that does not go well.

7. The ongoing implementation in social life that ignores the democratic process causes the people to be unable to channel their political aspirations, resulting in political turmoil that leads to community movements demanding freedom, equality, and justice.

8. The misuse of power as a result of poor internal government and people's representative institutions' oversight and restricted public and mass media oversight in the past has made the government's openness and accountability to execute a clean and responsible government non-existent. As a result, public trust in state administrators is reduced.

9. Globalisation in political, economic, social, and cultural life can benefit the Indonesian people. Still, if we are not careful, it can harm the nation's life.

10. Lack of awareness, appreciation, and belief in the principles inherent in each of the Pancasila precepts and their interrelationships must be regularly practised in all layers and domains of national and state life.

\section{Main Heading}

Today, the nation must ultimately resolve the various problem through the development process to create a better national unity and integrity. Therefore, the following conditions are required:

1. The realisation of religious values and national cultural values as a source of ethics and morals to do good and avoid disgraceful acts and actions contrary to law and human rights.

2. The realisation of state administration can understand and manage national pluralism reasonably and fairly so that tolerance, social harmony, togetherness and national equality can be realised.

3. The establishment of a legal system based on philosophical values oriented to truth and justice, social values oriented to values that apply and benefit the community and juridical values that rely on laws and regulations that guarantee order and legal certainty.

4. The improvement of the national economy, especially the people's economy, so that the people's economic burden and unemployment can be reduced, encouraging optimism and enthusiasm in the economy.

5. The realisation of a democratic political system can give birth to selecting leaders who are trusted by the community.

6. The realisation of a democratic, orderly and peaceful transition of power.

\footnotetext{
${ }^{8}$ Susana Tjipto and Allan B. I. Bernardo, "Constraints in the Meanings of Lay Theories of Culture in a Culturally Homogeneous Society: A Mixed-Methods Study on Multiculturalism and Polyculturalism in Wonosobo, Indonesia," Cogent Psychology 6, no. 1 (2019), https://doi.org/10.1080/23311908.2019.1569835.
} 
7. The realisation of democracy guarantees the rights and obligations of the people to be involved in making political decisions freely and responsibly to raise awareness to strengthen national unity.

8. The implementation of regional autonomy somewhat gives the regions the authority to manage their regions while maintaining insight into national unity and integrity.

9. The restoration of public trust in state administrators and among fellow citizens can be the basis for harmony in the life of the state.

10. Increasing professionalism and restoring the image of the Indonesian National Armed Forces and the Indonesian National Police for the sake of creating a sense of security and order in society.

11. The formation of quality Indonesian human resources who can work together and are competitive to obtain positive benefits from globalisation.

12. The process of interpreting Pancasila, namely the essential grounding of ideas so that Pancasila is implemented, is solid, practical, and is used as a guide in organising and managing the country.

There needs to be a policy direction that is a solution to the problems that occur in people's lives to strengthen the unity and integrity of the nation from the various challenges facing the nation today. The direction of the policy is following the Decree of the People's Consultative Assembly Number V/MPR/2000 concerning the Consolidation of National Unity and Unity as follows:

1. Making religious values and cultural values of the nation as a source of ethics for the life of the nation and state to strengthen the morals and morals of state and community administrators.

2. Making Pancasila an open state ideology by opening open discourse and dialogue in society to answer challenges under Indonesia's future vision. ${ }^{9}$

3. Increase social harmony between and between followers of religions, ethnic groups, and other community groups through dialogue and cooperation with the principles of togetherness, equality, tolerance and mutual respect. Government intervention in sociocultural life needs to be reduced, while community potentials and initiatives need to be increased.

4. Uphold the rule of law and legislation consistently and responsibly and guarantee and respect human rights. This step must be preceded by processing and resolving various cases of corruption, collusion, and nepotism, as well as human rights violations.

5. Increasing the prosperity and welfare of the community, primarily through economic development based on empowering the people's and regional economies.

6. Empowering the community through the improvement of a democratic political system can produce quality leaders who are responsible, become role models for the community, and unite the nation and state. ${ }^{10}$

7. Regulate power transfer in an orderly, peaceful, and democratic manner following laws and regulations.

8. Organising political life so that the distribution of power can take place in a balanced manner in various levels of political structure and power relations. Every political decision must go through a democratic and transparent process by upholding the people's sovereignty.

9. Implement regional autonomy policies, implement a fair financial balance, increase the distribution of public services, improve disparities in economic development and

\footnotetext{
${ }^{9}$ Oetojo Oesman and Alfian, Pancasila Sebagai Ideologi Dalam Berbagai Bidang Kehidupan Bermasyarakat, Berbangsa Dan Bernegara (Jakarta: Departemen Penerangan, 1991).

10 Morgan Brigg et al., "Diversity, Democratisation and Indonesian Leadership," Australian Journal of International Affairs 70, no. 4 (2016): 407-21, https://doi.org/10.1080/10357718.2016.1153599.
} 
regional income, and respect regional cultural values based on the constitutional mandate.

10. Improving integrity, professionalism, and responsibility in the administration of the state and empowering the public to exercise social control constructively and effectively.

11. To make the Indonesian National Army effective as a state instrument that plays a role in the defence sector and the Indonesian National Police as a state instrument that plays a role in the security sector, and to restore the identity of the Indonesian National Army and the Indonesian National Police as part of the people.

12. Improving the ability of Indonesian human resources so that they can work together and compete as a nation and citizens of the world while remaining oriented towards national unity and integrity. ${ }^{11}$

13. Restoring Pancasila as the state ideology, developing Pancasila as an ideology and as the basis for laws and regulations, trying to make Pancasila consistent with legal products, which initially only served vertical interests! (the state) becomes Pancasila which serves horizontal interests, and makes Pancasila a critique of state policy. ${ }^{12}$

By observing the conditions of the past, present and future challenges to reaffirm the sense of nationality, it is necessary to understand the values of the Four Pillars of National and State Life which refers to the ideals of unity and integrity, resilience, and independence which are imbued with religious values. Noble nation values consist of prioritising honesty, trustworthiness, exemplary, and responsibility to maintain the honour and dignity of the nation.

Policy directions can be made to actualise the nation's noble religious and cultural values in personal, family, community, nation, and state life, both through formal and non-formal education. This direction aims to build an understanding of the values of the Four Pillars of National and State Life in global conditions. As well as providing examples of exemplary by the nation's leaders. ${ }^{13}$

Efforts in implementing Pancasila are significant because Pancasila is more operational in life and state administration, can meet practical or pragmatic needs and is functional. Thus, philosophical-abstraction thoughts will become more meaningful if implemented in the life of the nation and state. Furthermore, it is vital to focus on organising the nation's and state's life towards a better future, as mentioned in the Preamble to the Republic of Indonesia's Constitution of 1945, to realise the ideals of reform to solve the nation's state's problems. ${ }^{14}$

\section{Conclusion}

Indonesian noble ideas were by the country's founder, as stated in the second and fourth paragraphs of the Preamble to the 1945 Constitution of the Republic of Indonesia. These lofty ideals are ideals that must always be pursued. However, in its achievements, the nation and state face various challenges different from time to time, both from within and outside the country.

To face these challenges, based on the Decree of the People's Consultative Assembly Number VII/MPR/2001 concerning the Vision of Future Indonesia, the following efforts need to be made:

1. Consolidation of national unity and state unity. The plurality of ethnicity, race, religion, and culture is a nation's wealth that must be accepted and respected. Proper management

\footnotetext{
${ }^{11}$ Dardji Darmodihardjo, Orientasi Singkat Pancasila (Malang: Humas Brawijaya, 1974).

12 David M. Bourchier, "Two Decades of Ideological Contestation in Indonesia: From Democratic Cosmopolitanism to Religious Nationalism," Journal of Contemporary Asia 49, no. 5 (2019): 713-33, https://doi.org/10.1080/00472336.2019.1590620.

13 Al Makin, "'Not a Religious State,"” Indonesia and the Malay World 46, no. 135 (2018): 95-116, https://doi.org/10.1080/13639811.2017.1380279.

14 A. M. W. Pranarka, Sejarah Pemikiran Tentang Pancasila (Jakarta: Yayasan Proklamasi Centre for Strategic and International Studies, 1985).
} 
of national pluralism is a challenge in maintaining national integration and integrity. The unequal distribution of the population and the management of regional autonomy using the concept of an archipelagic state following the Archipelago Insight are challenges for regional development within the scope of the Unitary State of the Republic of Indonesia. In addition, the influence of globalisation is also a challenge for strengthening national unity and national unity.

2. A fair legal system. All citizens are equal before the law and are entitled to justice. The law is enforced for justice and not for the interests of power or specific interest groups. The challenge to uphold justice is the realisation of a just rule of law and legal institutions and law enforcement officers who are honest, professional, and not influenced by the authorities. The rule of law is enforced to ensure legal certainty, justice, and the defence of human rights.

3. A democratic political system. The challenges of a democratic political system are the realisation of sovereignty in the hands of the people, high people's participation in political life, aspirational and influential political parties, quality general elections. A healthy political culture supports a democratic political system, namely sportsmanship, respect for differences, politeness in behaviour, prioritising peace, and non-violence in various forms. This is expected to give birth to a democratic, strong and effective national leadership.

4. A just and productive economic system. The challenge for a just and productive economic system is the realisation of an economy that favours the people and ensures a fair and independent economic incentive system. The economic system is based on people's activities that utilise natural resources optimally and sustainably, especially those from agriculture, forestry, and marine affairs. To realise this economic system, competent human resources and economic mechanisms are needed to absorb labour. In addition, the state develops the economy by processing resources and other industries, including the service industry.

5. Civilised socio-cultural system. The challenge for the realisation of a civilised social system is the maintenance and actualisation of universal values taught by every religion and the noble values of the nation's culture so that freedom of expression is realised in the context of enlightenment, appreciation, and practice of religion and cultural diversity. A civilised social system prioritises the realisation of a society that has mutual trust and love for each other, both towards fellow citizens and between the community and public institutions. Improving the quality of people's lives includes improving the quality of education, health services, providing employment opportunities, increasing people's income, feeling safe, and other elements of people's welfare.

6. Quality human resources. The challenge in developing quality human resources is the realisation of a quality education system that can produce reliable and noble human resources who can work together and compete in the era of globalisation while still loving the homeland. These quality human resources have faith and piety and master science and technology, have a work ethic and build a productive and personal work culture.

7. Globalisation. The challenge in facing globalisation is to maintain the nation and state's existence and integrity and take advantage of opportunities for the progress of the nation and state. To face globalisation, it is necessary to have the capacity of human resources and institutions, both in the state sector and in the private sector.

As a unifier of the nation, Pancasila is needed by all nation generations. Even though the Indonesian people are now united, it does not mean that Pancasila is no longer needed. Because what is called the Indonesian nation is what is currently there and what will exist in the future. As long as the regeneration process continues, we still need Pancasila as a unifying nation. That 
means, as long as there is an Indonesian nation, we still need a unifying tool for the nation. This signifies that as long as the Indonesian country exists, Pancasila will be required as the state's foundation. This also confirms Pancasila's truth as the foundation of the state and other interests, demonstrating that Pancasila has various purposes or is multifunctional.

\section{Acknowledgements}

Praise and gratitude the author prays to the presence of God Almighty because of His blessings and grace. The author was able to complete this paper. Therefore, on this occasion, the author would like to thank all those who have helped directly or indirectly who cannot be mentioned one by one to help the writer find references and ideas related to this paper.

\section{Bibliography}

\section{A. Journal}

Bourchier, David M. "Two Decades of Ideological Contestation in Indonesia: From Democratic Cosmopolitanism to Religious Nationalism." Journal of Contemporary Asia 49, no. 5 (2019): 713-33. https://doi.org/10.1080/00472336.2019.1590620.

Brigg, Morgan, Lee Wilson, Frans de Jalong, and Muhadi Sugiono. "Diversity, Democratisation and Indonesian Leadership." Australian Journal of International Affairs 70, no. 4 (2016): 407-21. https://doi.org/10.1080/10357718.2016.1153599.

Iskandar, Pranoto. "The Pancasila Delusion." Journal of Contemporary Asia 46, no. 4 (2016): 723-35. https://doi.org/10.1080/00472336.2016.1195430.

Makin, Al. "'Not a Religious State."” Indonesia and the Malay World 46, no. 135 (2018): 95116. https://doi.org/10.1080/13639811.2017.1380279.

Tjipto, Susana, and Allan B. I. Bernardo. "Constraints in the Meanings of Lay Theories of Culture in a Culturally Homogeneous Society: A Mixed-Methods Study on Multiculturalism and Polyculturalism in Wonosobo, Indonesia." Cogent Psychology 6, no. 1 (2019). https://doi.org/10.1080/23311908.2019.1569835.

\section{B. Book}

Darmodihardjo, Dardji. Orientasi Singkat Pancasila. Malang: Humas Brawijaya, 1974.

Moedjanto, G. Pancasila: Buku Panduan Mahasiswa. Jakarta: Gramedia Pustaka Utama, 1989. Notonagoro. Pancasila Dasar Falsafah Negara. Jakarta: Bina Aksara, 1988.

Oesman, Oetojo, and Alfian. Pancasila Sebagai Ideologi Dalam Berbagai Bidang Kehidupan Bermasyarakat, Berbangsa Dan Bernegara. Jakarta: Departemen Penerangan, 1991.

Pranarka, A. M. W. Sejarah Pemikiran Tentang Pancasila. Jakarta: Yayasan Proklamasi Centre for Strategic and International Studies, 1985.

Sunoto. Mengenal Filsafat Pancasila (Etika Pancasila). 3rd ed. Yogyakarta: UII Press, 1982.

Wahyono, Padmo. Bahan-Bahan Pedoman Penghayatan Dan Pengamalan Pancasila. Jakarta: Rineka Cipta, 1993.

Yamin, Muhammad. Naskah Persiapan Undang-Undang Dasar 1945. Jakarta: Jajasan Prapantja, 1959.

\section{Regulations}

Law No. 39/1999 on Human Rights 